\title{
Margaret Wrong Memorial Fund Bursary
}

The Margaret Wrong Bursary for 1965 has been awarded to Mr. Menbere Wolde, of Addis Ababa, Ethiopia, who is now at the African Literature Centre, Kitwe, Zambia. Mr. Wolde speaks and writes Amharic and English and has been working with the Literature Society of the Mennonite Mission in Ethiopia, editing a book in Amharic on the life of Abraham. Before going to Kitwe he translated a correspondence course from English into Amharic and prepared a story for new literates on the life of David.

\section{Reopening of the Musée Provincial du Katanga}

THE Musée Léopold II at Elisabethville, which was partly destroyed in 1961 , has now been reopened as the Musée Provincial du Katanga. Mr. A. Schmits acted as curator during 1963 and managed to salvage about half the original ethnographic collection and some of the prehistoric items. In 1964 the authorities of the province of East Katanga (Commissariat à la Jeunesse, aux Sports et aux Affaires Culturelles) made a grant for the repair of the buildings and the purchase of furniture and materials. The present curator is Dr. R. R. De Poerck, of the University of Ghent, a specialist in archaeology and the history of primitive art, who is assisted by a staff of seven Congolese. The ethnographic collections belonging to a private society ('Les Amis du Musée') have been loaned to the province, and efforts are being made to build up the library of more than 4,000 books and periodicals which has been severely depleted.

\section{Afro-Asian Books in English}

Two monthly check-lists of books for Asia and Africa will be published regularly from April 1966 by K. K. Roy (Private) Ltd., 55 Gariahat Road, P.O. Box roz 10, Calcutta-19, India. The lists will cover all books published in English in most Asian and African countries, excluding elementary textbooks and children's books, and will be available on subscription basis.

\section{Library of Congress Bibliography for Rhodesias and Nyasaland}

THE Library of Congress has published the tenth in its series of guides to the documents of African governments, The Rhodesias and Nyasaland: $A$ Guide to Official Publications. The new guide is compiled by Audrey A. Walker and contain I,889 entries covering as comprehensively as possible the published records of administration in the former Federation of Rhodesia and Nyasaland from 1889 to 1963 ; it includes selected British documents pertaining to the Federation and its component territories, and major publications by the British South Africa Company. It may be obtained from the Superintendent of Documents, U.S. Government Printing Office, Washington, D.C. 20402, at $\$ 1.50$ a copy.

\section{Anthropological Bibliography of Nigeria}

Mr. N. O. ITA, Sub-Librarian of the Nnamdi Azikwe Library, University of Nigeria, Nsukka, has been working for two years on a bibliography which will include anthropological, archaeological, linguistic, and relevant sociological studies bearing on the various peoples of Nigeria. It will be limited to published materials (books, pamphlets, and articles 
in periodicals) in any languages other than Arabic, although relevant unpublished theses and dissertations will be included. It is planned to limit the work to between 4,000 and 5,000 titles, most of which will be supplied with indicative and informative annotations. The bibliography is expected to be ready for publication by the end of this year.

\section{CARDAN and Centre of African Studies, Cambridge: Bibliography Cards}

LE Centre d'Analyse et de Recherche Documentaires pour l'Afrique Noire and the University of Cambridge Centre of African Studies are publishing jointly Bibliography Cards on Current Literature on Black Africa in the Field of the Social Sciences: books, theses, government documents, conference proceedings, cyclostyled material, and articles from about 800 periodicals, in all European languages, and it is hoped soon to include material in Chinese and Japanese.

Subscribers will receive about 7,000 cards annually, a copy of the classification system used and a list of the 800 periodicals indexed. Cards will be dispatched four times a year in the form of sheets, ready to cut up, each containing eight $5^{\prime \prime} \times 3^{\prime \prime}$ cards. These sheets come in two thicknesses: ordinary paper, for those who do not wish to cut up the entries; Bristol paper, card weight, for those who intend to file.

Each card carries a CARDAN serial number and classification by subject and region. Subscribers may cut up and file the cards as they please, but those who keep author, subject, and region files, will need several sets of cards. With the final mailing each year a cumulative subject index is sent out, also in the form of sheets for cutting into cards. 'This means that a subscriber need only cut up the cumulative subject index to have subject references to all the year's entries.

The cards themselves fall into three categories:

I. Cards with abstracts (A.C.) These contain bibliographical references to periodical articles, symposia, cyclostyled material, conference proceedings, etc. with short abstracts.

2. Descriptive or simple index cards (D.C.) These contain bibliographical references to articles of interest to research workers, but which are too short, too specialized, or too ephemeral to be worth giving abstracts.

3. Cards of books and other major works (B.C.) These appear as a separate publication and will complete the bibliographical references provided by the A.C. and D.C. These cards do not contain abstracts but provide notes of explanation where titles are not sufficiently selfexplanatory, and subject and regional classification. The B.C. will be published once yearly (about May) and will contain references to all works published in the previous year. References to the B.C. will appear in the annual cumulative subject index sent with the A.C. and D.C.

\section{Terms of subscription}

A.C. and D.C.--four numbers per year +cumulative index, list of key-words and list of periodicals:

$\begin{array}{llll}\text { Bristol paper } & \text { NF } 300 & £_{22} & \$ 60 \\ \text { Ordinary paper } & \text { NF } \text { I50 }^{\prime} & £_{11} & \$ 30 \\ \text { Ordinary paper sent airmail } & \text { NF 250 } & £_{18} & \$ 50\end{array}$

B.C.- one number each year:

$\begin{array}{llll}\text { Bristol paper } & \text { NF 80 } & £ 6 & \$ 16 \\ \text { Ordinary paper } & \text { NF } 40 & £ 3 & \$ 8\end{array}$

